レーザーオリジナル

\title{
電子ビーム励起 $\mathrm{KrF}^{*} レ$ ザーの電子脱励起速度の測定
}

\author{
西岡 一*・佐々木 明**. 倉 嶋利 雄*・倉 西 英 明* \\ 植田憲一*.宅間 宏*.糟谷紘一**
}

（1988年 5 月 6 日 受理）

\section{Measurement of the Electron Quenching Rate in an Electron Beam Pumped $\mathrm{KrF}^{*}$ Laser}

\author{
Hajime NISHIOKA*, Akira SASAKI** Toshio KURASHIMA* \\ Hideaki KURANISHI* Kenichi UEDA* Hiroshi TAKUMA* \\ and Koichi KASUYA**
}

(Received May 6, 1988)

The electron quenching rate of $\mathrm{KrF}^{*}$ in an electron beam pumped laser has been studied by accurately measuring the saturation intensity in a mixture of $\mathrm{Ar} / \mathrm{Kr} / \mathrm{F}_{2}=94 / 6 / 0.284$. The input intensity of the measurements was widely varied from $100 \mathrm{~W} \mathrm{~cm}^{-2}$ (small signal region) to 100 $\mathrm{MW} \mathrm{cm}^{-2}$ (absorption dominant region) in order to separate laser parameters which are small signal gain coefficient, absorption coefficient, and saturation intensity from the measured net gain coefficients. The gas pressure and the pump rate were varied in the range of 0.5 to 2.5 atm and 0.3 to $1.4 \mathrm{MW} \mathrm{cm}{ }^{-3}$, respectively. The electron quenching rate constant of $4.5 \times 10^{-7} \mathrm{~cm}^{3} \mathrm{~s}^{-1}$ was obtained from the pressure and the pump rate dependence of the $\mathrm{KrF}^{*}$ saturation intensity with the temperature dependence of the rate gas 3-body quenching rate as a function of gas temperature to the -3 rd power. The small signal gain coefficients calculated with the determined quenching rate constants shows excellent agreement with the measurements.

Key Words: KrF laser, Electron quenching, Gain measurement, Electron beam.

\section{1.はじめに}

KrFレーザーは，紫外域で発振するエキシマ レーザーの中で, 最も高出力が期待できる ${ }^{1)} レ$ ーザーである。エキシマレーザーは，レーザー 媒質の冷却が容易である気体レーザーの長所を
合わせ持ち, 繰り返し動作の容易な放電励起工 キシマレーザーは半導体加工用レーザーなどと して, 実用的な応用を目指す分野でも, 活発に 研究開発が行われている。気体レーザーのもう 一つの長所は, 大型化の容易な事である。 $\mathrm{KrF}$ レーザーは, 電子ビーム励起を用いる事によっ

*電気通信大学新形レーザー研究センター（テ 182 調布市調布ヶ丘 $1-5-1$ )

** 東京工業大学大学院総合理工学研究科工ネルギー科学専攻（テ227 横浜市緑区長津田2459）

* Institute for Laser Science, The University of Electro-Communications (1-5-1 Chofugaoka, Chofushi, 182)

** Tokyo Institute of Technology, Department of Energy Science, The Graduate School at Nagatsuta (4259 Nagatsuta, Midoriku, Yokohama, Kanagawa 227) 
て数 $100 \mathrm{~kJ}$ オーダーの増幅器を構成できる可能 性 ${ }^{1,2)}$ を持っており，慣性核融合（Inertial Confinement Fusion; ICF) のドライバーとし てレーザー装置, ASE (Amplified Spontaneous Emission) ${ }^{3,4}$, 内部反応機構の研究が行な

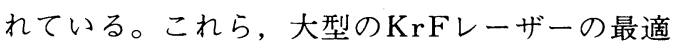
動作条件を論じるためには, 正確な反応定数の 測定 $^{5,6}$, 吸収断面積の測定 ${ }^{7)}$ に加え, 実際にレ 一ザー増幅器の動作特性を調べ, シミュレーシ ヨンコード ${ }^{81}$ のモデルや反応定数を検証する必 要がある。中でも, 反応定数が直接測定困難な 場合や，レーザー動作条件と大きく異なる条件 において測定された反応速度定数のレーザー動 作条件における妥当性を論じるためには,レー ザー增幅特性の把握は欠くことができない。特 に, 励起強度や圧力, $\mathrm{Kr}$ 濃度等 ${ }^{9,10}$ に関する 増幅特性の振舞は, 大型レーザーの設計や反応 機構の理解に多くの情報を与えると言えよう。

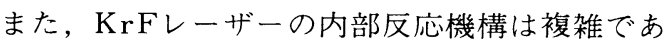
り, 電子密度やガス温度が反応過程に大きく影 響する。特に, $\mathrm{KrF}^{*}$ の脱励起は電子 ${ }^{11}$ ’ や希ガ スの 3 体衝突による割合が大きく, 3 体脱励起 速度はガス温度に影響 ${ }^{12,13,14}$ される。従って, 脱励起過程の正確な見積りには, 電子密度やガ ス温度を一様に保った測定空間が必要であるが, その実現は一般に容易でない。ところが, 大型 装置を用いた増幅実験 ${ }^{10,15,16}$ 、では, 大型レーザ 一増幅器は大きな測定空間 (レーザー媒質)を均 一に励起できる上に，プローブレーザー光が測 定空間を限定しているので, 励起分布や境界条 件の影響を全く排除した理想的な測定对象を実 現できる。これは、レーザー動作条件における 反応速度を測定する上で大きな利点となりうる。 本論文では，入力光強度を非常に広い範囲 $\left(100 \mathrm{~W} \mathrm{~cm}^{-2} \sim 100 \mathrm{MWcm}^{-2}\right)$ に渡って変化させ, 小信号利得係数 $g_{0}$, 吸収係数 $\alpha$, 飽和光強度 $I_{\mathrm{s}}$ を決定し，レーザー出力のレーザーパラメータ 一依存性に基づいて, $\mathrm{KrF}^{*} レ$ ザーの脱励起 過程について考察する。また, 励起強度, 圧力 の変化に対し脱励起反応を詳細に調べ，レーザ 一動作条件における実効的な電子脱励起速度を
決定した結果について報告する。

\section{2 . 高入力光強度利得測定}

レーザー増幅特性を一般化し, 表現するため には小信号利得 $g_{\mathrm{o}}$, 飽和光強度 $I_{\mathrm{s}}$ をパラメータ 一とする表式が広く用いられている。しかしな がら, エキシマレーザーは他の多くのレーザー と異なり, 発振波長にレーザー媒質自身の吸収 を持っている。このため, 増幅特性の記述のた めにはもう 1 つのパラメーターとして非飽和吸 収係数 $\alpha$ が必要である。堌幅特性をこれら3つ のパラメーターを使って記述する自由度は， 2 パラメーターの場合よりも遥かに多く, $\operatorname{Rigrod}^{29}$ 解析によるエキシマレーザーの正確なパラメー ター決定が難しい原因となっている。パラメー ターの正確な分離には, 個々のパラメーターを そのパラメーターの影響が一番大きな領域で決 定するのが有効な手段である。例えば, 入力光 強度を非常に高くし, 利得を強く飽和させると, 利得係数は吸収係数に比べ大変小さくなり，1 パス利得から直接吸収係数を精度よく決定でき る。一方, 入力光強度を非常に小さくすれば, 小信号利得と吸収係数の差 $g_{0}$ - $\alpha$ を決定できる。 この増幅実験では，このような境界条件を明確 にしたパラメーター決定を行うために, 入力光 強度を $100 \mathrm{~W} \mathrm{~cm}^{-2}$ から利得飽和光強度の50倍に 相当する $100 \mathrm{MW} \mathrm{cm}^{-2}$ まで $10^{6}$ 倍变化させ測定を 行った。この広範囲な増幅特性を記述できるレ ーザーパラメーターは 1 組であり, パラメータ 一の正確な分離が可能である。

\section{3. 実験装置}

測定に用いた増幅器は, $500 \mathrm{~J}$ 級KrFレーザー システム 2 の初段増幅器に用いている横方向電 子ビーム励起 $\mathrm{KrF}$ レーザー増幅器であり, $80 \mathrm{~J}$ /パルスのエネルギーを120nsで出力できる。電

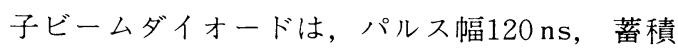
エネルギー $1.67 \mathrm{~kJ}$ の水誘電体平行平板ブルーム ラインによりレールギャップを通じて駆動され る。このブルームラインのスイッチには, $\mathrm{SF}_{6}$ を満たしたレーザートリガギャップ（LTSG） 


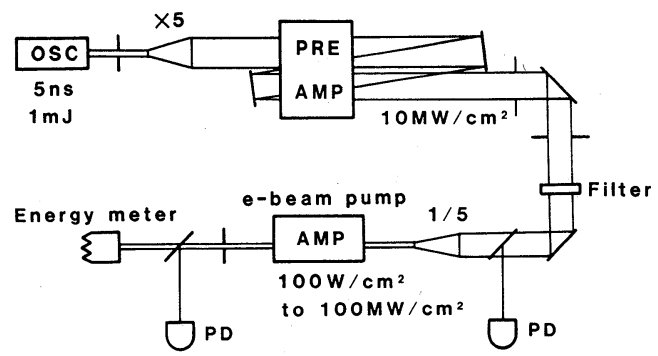

Fig. 1 Experimental setup for the widerange gain meaurements. The diffraction limited output of the master oscillator is magnified 5 in diameter and is amplified by the 3-pass electron beam pumped preamplifier. PD are photo-diode monitors for the input and output intensity. The input intensity is varied with a liquid UV filter ( IMP).

が用いられ，KrFレーザーの照射によって他の 電子ビーム装置や測定機器と $1 \mathrm{~ns}$ 以下のジッ夕 一で同期させ得る。電子ビームカソードは, 長 さ $70 \mathrm{~cm}$, 幅 $4 \mathrm{~cm}$ の大きざ， ステンレスのチー ズグレータータイプである。アノード及び圧力 膜には，低電圧・大電流密度ダイオード用に開 発したCCK膜 (Carbon Coated Kapton) 膜 ${ }^{17}$ を用いた。この電子ビームダイオードの典型的 な電圧・電流は $270 \mathrm{kV}, 27 \mathrm{kA} ゙$ ある。

増幅実験に用いる事のできる入力光強度の上 限は,レーザー増幅器の入力空に用いる合成石 英のレーザー損傷䦨值で制限される。この制限 内で可能な限り高い入力光強度を得るために, レーザー上準位に対し定常状態が仮定できる範 囲で，入力光パルス幅を短くする事を考え，発 振器としてパルス幅 $5 \mathrm{~ns}$ の放電型レーザー（M SNW社EXCI-LITE XL-410）を用いた。この 放電型レーザーには，不安定共振器を取付け， そのビーム広がり角を回折限界まで抑えてある。 Fig.1のように，このレーザー光を $\times 5$ のテレ スコープにより広げ, 電子ビーム励起增幅器に より 3 パス増幅する事により, 必要なレーザー エネルギーを得た。 2 パス， 3 パスは，増幅器 内部で空間的に重なる様に配置し，利得の飽和 効果によってレーザーパルスが長く尾を引くこ

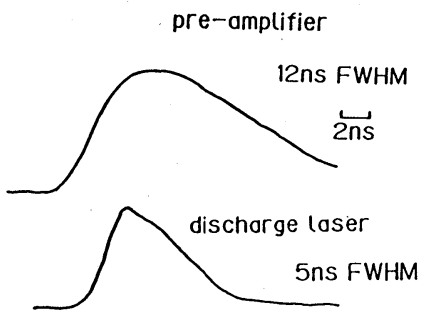

\section{Damage threshold of fused silica for 12ns KrF laser}

\begin{tabular}{lr}
\hline damage free & $<200 \mathrm{MW} / \mathrm{cm}^{2}$ \\
multiple shot & $400 \mathrm{MW} / \mathrm{cm}^{2}$ \\
single shot & $600 \mathrm{MW} / \mathrm{cm}^{2}$ \\
\hline
\end{tabular}

Fig. 2 Typical waveform of the master oscillator and the preamplifier output. Damage free operation is verified below $200 \mathrm{MW} \mathrm{cm}^{-2}$.

とを防いだ。また，レーザービーム伝播路をパ イプにより囲い，実験室内部の空気の流れがレ 一ザービームを擾乱しないようにした。Fig. 2 は, Tektronix-7104オシロスコープ, HAMA MATSU R1193U-02フォトダイオードにより観 測した 3 パス増幅器出力波形と増幅前の放電型 レーザー波形である。飽和増幅によってパルス の立ち上がりや尾が大きくなり, 増幅後のレー ザーパルスの半值全幅は $12 \mathrm{~ns}$ になった。このプ ローブビームによって合成石英のレーザー損傷 閾值を測定した所, $200 \mathrm{MW} \mathrm{cm}^{-2}$ までは, 多数回 照射を行っても，何等損傷を生ずる事なく使用 可能であった。この入力光強度は, 典型的な利 得飽和光強度 ${ }^{10}$ の100倍に相当し, 利得を完全 飽和させるためには十分な光強度である。入力 光強度の調節は, 縮小光学系の低光強度側に置 いた IMP (Inosic Mono Phosphate) フィル ターにより光を減衰させることによって行った。 $\mathrm{IMP}$ 水溶液は, $\mathrm{KrF}$ レーザーの発振波長 $249 \mathrm{~nm}$ に吸収の極大值を持ち，KrFレーザー光の減衰 に格好の液体フィルターである。測定したこの フィルターの透過率は, $100 \mathrm{~W} \mathrm{~cm}^{-2}$ から $10 \mathrm{M} \mathrm{W}$ $\mathrm{cm}^{-2}$ まで完全に一定であり, 且つ, $10^{3}$ 回のレー ザ一照射を行っても劣化は認められなかった。 
励起長は, 高励起強度 $\left(>0.9 \mathrm{MW} \mathrm{cm}^{-3}\right)$ では ASE (Amplified Spontaneous Emission) の影響によって利得飽和を生じないように $40 \mathrm{~cm}$ に制限し, 低励起強度では, 測定感度を上げる ために $70 \mathrm{~cm}$ で行った。レーザー悹は, 表面反射 による奇生発振を避けるために光軸に対し 5 度 傾けて取付けた。入力レーザーは, 被測定増幅 器の励起開始から一定の時刻 $(75 \mathrm{~ns})$ に入射す るようにLTSGを用いてタイミングを定めた。 出力光エネルギーは, SCIENTEK MODEL 38-0103カロリーメーターによって測定し，入 出力フォトダイオードの校正に用いた。レーザ 一ガスは, $\mathrm{F}_{2}$ 分圧, $\mathrm{Kr}$ 分圧を各々 $0.284 \%, 6$ \%に固定して測定した。

増幅実験の精度は, 入出力光強度の測定精度 のみでなく，被測定空間へのデポジションエネ ルギー測定精度に大きく依存する。励起密度の 決定は, 電子ビームによるレーザーセル全体へ のエネルギー注大量をプレッシャージャンプ法 によって測定し，励起空間分布を連続エネルギ ギー損失モデルを用いたモンテカルロ法コード30 によって行った。この計算機コードは，アノー ド及び圧力膜の散乱効果やレーザーガスとレー ザーセル間等の境界条件を考虑している。また， カソード面上の電流分布をセグメントチャージ コレクターにより測定し, 計算機コードの入射 電流密度分布を与えた。Fig. 3 に, 圧カレーザ 一ガス圧力 $1.76 \mathrm{~atm}$ 場合の励起強度分布を示 す。増幅特性の励起強度依存性は, この励起強 度の空間分布を用いて, プローブレーザーの光 軸の圧力膜からの距離を変え, 励起強度を0.3 $1.4 \mathrm{MW} \mathrm{cm}^{-3}$ まで変化させて行った。また, 圧力 依存性の測定は，プローブレーザーの光軸を圧力 膜から $1.5 \mathrm{~cm}$ の距離に保ったまま，レーザーガ ス圧力を $0.5 \mathrm{~atm} \sim 2.5 \mathrm{~atm}$ 変化させて测定 を行った。このときの励起強度は，1.76 a tm に おいて $1.4 \mathrm{MW} \mathrm{cm}^{-3} て ゙ あ り ， 0.5 \mathrm{~atm}$ か $2.5 \mathrm{~atm}$ までの範囲では，レーザーガス圧力に比例して いた。

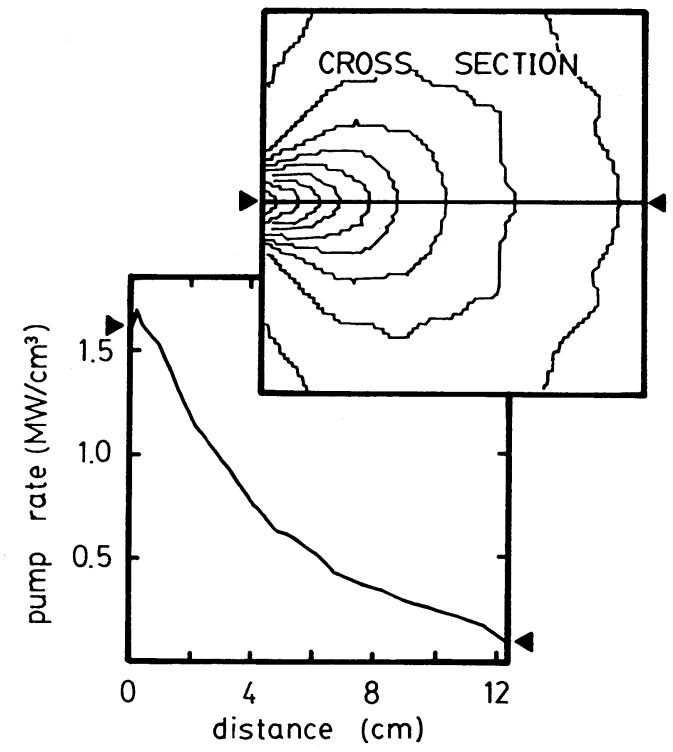

Fig. 3 Calculated spatial distribution of pump rates in the transversely pumped amplifies by an electron beam. The lower trace indicates the pump rate on the centralline of the upper 2 dimensional dist. ribution.

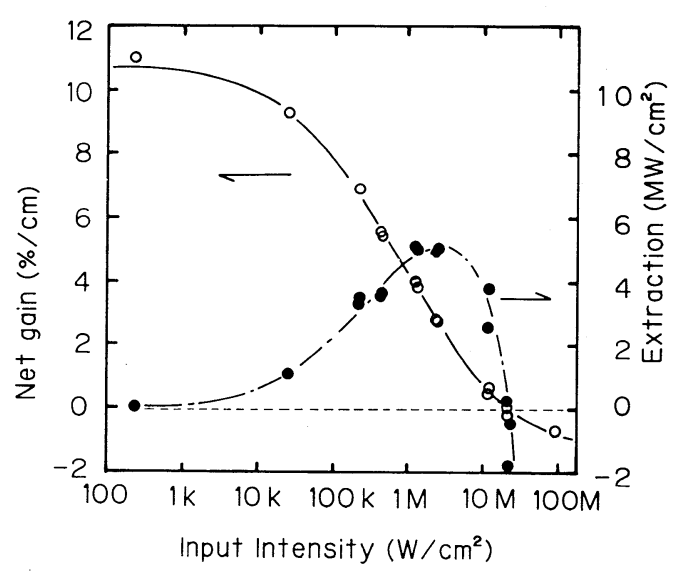

Fig. 4 Typical net gain (log of single pass gain and divided by active length) and extracted cncrgy as a function of input intensity. In the strongly saturated region around $100 \mathrm{MW} \mathrm{cm}^{-2}$, "non-saturable absorption" dominate the single pass gain of the amplifier. 


\section{4. 測定結果}

\section{1 励起強度依存性}

初めに, レーザーガス圧力を一定值 $1.76 \mathrm{~atm}$ に保ったまま, 励起強度を $0.3 \mathrm{MW} \mathrm{cm}^{-3} \sim 1.2 \mathrm{M}$ $\mathrm{W} \mathrm{cm}^{-3}$ の範囲で変化させて測定を行った。Fig. 4 に, 一例として, 圧力 $1.76 \mathrm{~atm}$, 励起強度 1.4 $\mathrm{MW} \mathrm{cm}^{-2}$ の入力光強度に対するネットゲイン $g_{\text {net }}$ と引き出しパワー $I_{\mathrm{ex}}$ の変化を示す。ここで, $g_{\text {net }}, I_{\text {ex }}$ は

$$
\begin{aligned}
& g_{\text {net }}=1 / L \cdot \log _{\mathrm{e}}\left(I_{\mathrm{o}} / I_{\mathrm{in}}\right) \\
& I_{\mathrm{ex}}=I_{\mathrm{o}}-I_{\mathrm{in}}
\end{aligned}
$$

である。ここで, $I_{\mathrm{in}}, I_{\mathrm{o}}$ はプローブ光の入出力 光強度, $L$ はレーザー増幅器の励起長である。 $g_{\text {net }}$, 入力光強度の増加に従って減少し, 約 $20 \mathrm{MW} \mathrm{cm}^{-2}$ 以上では, 飽和利得係数は吸収係数 よりも小さくなり，gnetは負の值を示した。更 に, 入力光強度を $100 \mathrm{MW} \mathrm{cm}^{-2}$ 付近まで増加させ ると, 利得は完全に飽和して $g_{\text {net }}$ は一定の「非 飽和吸収係数」を示した。Fig. 5 は, 各励起強 度に対する $g_{\text {net }}$ の変化を示す。励起強度が増加 するに従い, 小信号ネットゲイン, 零利得点, 吸収係数は増加している。ここで, レーザー上 準位に対し定常状態を仮定し， g net を次式のよ うにおいて最小二乗解析を行い, $g_{\text {net }}$ からレー ザーパラメーター $g_{0}, \alpha I_{\mathrm{s}}$ を決定した。

$I_{\mathrm{o}} / I_{\mathrm{in}}=\int_{0}^{\mathrm{L}} \exp \left(g_{\text {net }} \cdot \mathrm{d} z\right)$

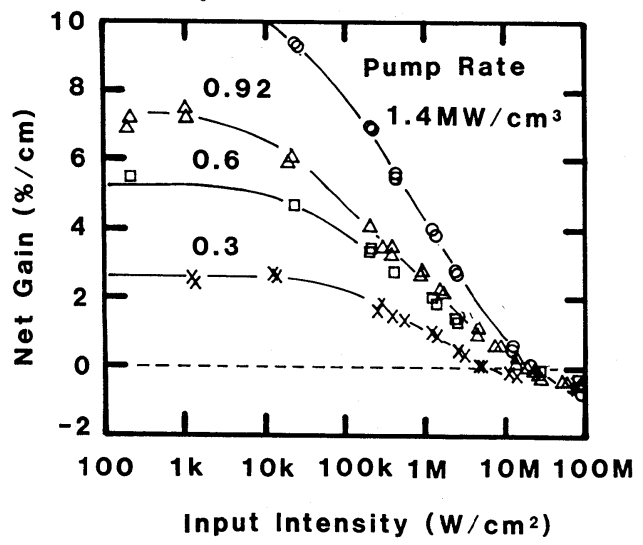

Fig. 5 Net gain curves for various values for the pump rate.

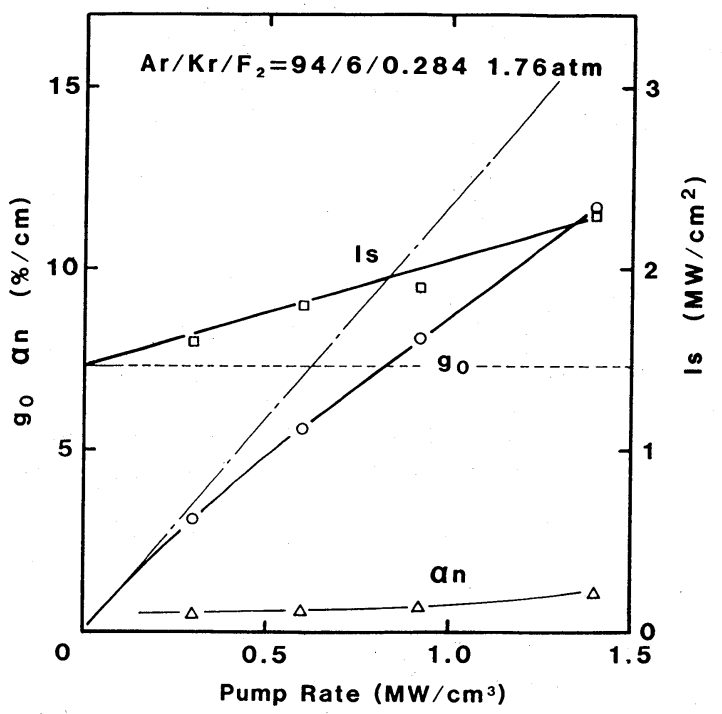

Fig. 6 Laser parameters as a function of the pump rate. Saturation intensity $I_{s}$ increases with the pump rate due to the growth of the electron quenching rate. The dash dotted line indicates small signal gain coefficients without the growth of quenching rate.

$$
g_{n e t}=\frac{g_{0}}{1+I / I_{s}}-\alpha
$$

ここで, $g_{0}, \alpha, I_{\mathrm{s}}$ は小信号利得係数, 非飽和吸 収係数, 飽和光強度である。また， $\alpha$ には完全 非飽和を仮定しているが, 後の圧力依存性の項 で述べるように，この圧力では吸収の飽和光強 度は非常に高く，飽和効果を無視できるためで ある。このようにして得た $g_{0}, \alpha, I_{\mathrm{s}}$ の励起強度 依存性をFig. 6 に示す。goは, 励起強度と共に 増加し, 強励起側で飽和する傾向が見られた。 図中の一点鎖線は，原点を通る直線を表してお り, 利得が励起強度に対して飽和している様子 がよく分かる。 $\alpha$ も励起強度と共に増加してい る。また, 上準位脱励起速度を反映している $I_{\mathrm{s}}$ は，ガス圧力が一定であるにもかかわらず，励 起強度とともに増加している。これは, 電子密 度の変化による電子脱励起速度の変化であると 考えられる。脱励起過程については, 後に詳し く述べる。

\section{2 圧力依存性}




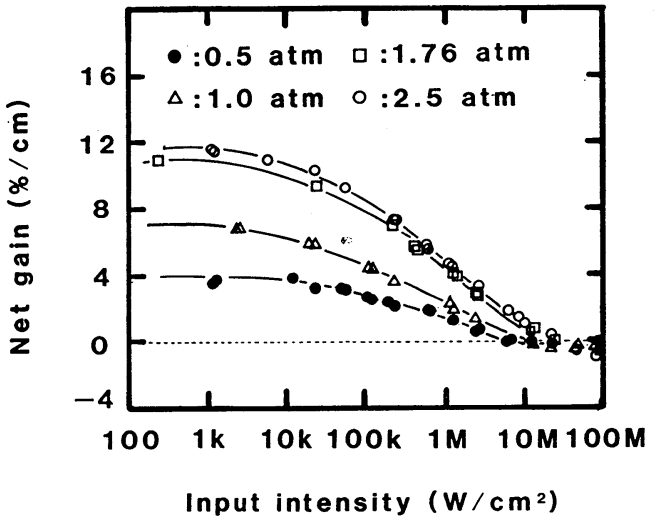

Fig. 7 Net gain curves under various pressures.

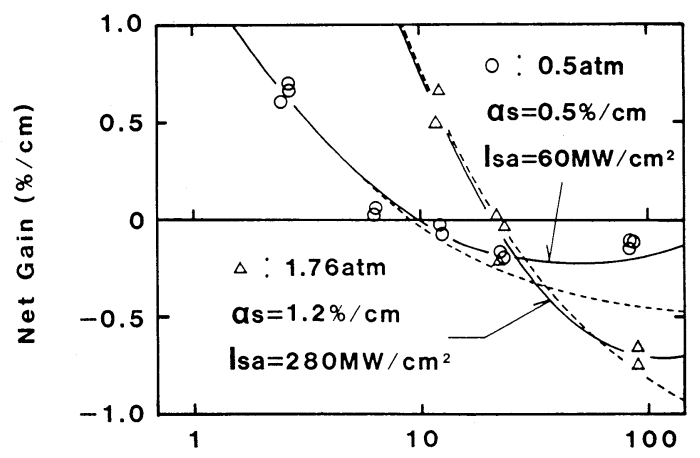

Input Intensity $\left(\mathrm{MW} / \mathrm{cm}^{2}\right)$

$\mathrm{Ar} / \mathrm{Kr} / \mathrm{F}_{2}=94 / 6 / 0.284$

Fig. 8 Magnified detail around zero gain points. A broken line for $0.5 \mathrm{~atm}$ represents the net gain curve including absorption saturation. The dashed line indicates net-gain curve without absorption saturation.

レーザーガス圧力を 0.5 2.5 atmまで変化さ せて測定を行った。Fig.7に，圧力をパラメー ターとして入力光強度に対するネットゲイン係 数 $g_{\text {net }}$ の振舞を示す。入力光強度の上昇と共に 利得は飽和し, 入力光強度数 $10 \mathrm{M} \mathrm{W} \mathrm{cm}^{-2}$ 以上で は, 利得は吸収係数より小さくなり, 増幅器は 負の利得を示した。また, 小信号利得, 零利得 点光強度, 吸収係数は, 圧力と共に増加を示し た。Fig. 8 は, 零利得点付近の拡大図である。 圧力 $0.5 \mathrm{~atm}$ では, $g_{\text {net }}$ は入力光強度の増加に従
つて減少し一旦極小值を示すが，さらに光強度 を表すと再び増加する様子を示した。g net $の$ 増 加は吸収係数の飽和と考える事ができる。これ

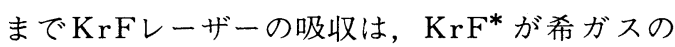
3 体衝突により生成する $\mathrm{Kr}_{2} \mathrm{~F}^{*}$ を除き，「非飽 和吸収」とされていた。しかし, 利得の飽和光 強度に比べ十分高いこの光強度における吸収飽 和は, $\mathrm{KrF}^{*}$ とほぼ等しい飽和強度を持つ $\mathrm{Kr}_{2}$ $\mathrm{F}^{*}$ 以外の吸収が飽和した事を示している。Fig. 8 における破線は, 吸収飽和を考虑しない場合 の $g_{\text {net }}$ の計算値を示しており，0.5atmでは吸収 飽和を考慮しなければ大きな食い違いを生じる。 従って，吸収飽和を考虑して $g_{\text {net }}$ を表現する事 を試みた。即ち,

$$
g_{\mathrm{net}}=\frac{g_{\mathrm{o}}}{1+I / I_{\mathrm{s}}}-\frac{\alpha_{\mathrm{s}}}{1+I / I_{\mathrm{sa}}}-\alpha_{\mathrm{n}}
$$

ここで, $g_{0}$ は小信号利得係数, $I_{s}$; 利得の飽和 光強度, $\alpha_{\mathrm{s}}$; 可飽和吸収係数, $I_{\mathrm{sa}}$; 吸収飽和光 強度, $\alpha_{\mathrm{n}}$; 非飽和吸収係数である。 $\mathrm{F}_{2}, \mathrm{Kr}_{2} \mathrm{~F}^{*}$

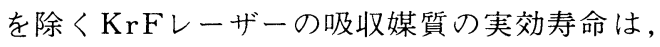
この実験の入力パルス幅よりも十分短く, 定常 解析が可能である。従って, その吸収断面積と 脱励起速度によって決まる光強度において吸収 飽和を示すと考え， $\mathrm{F}_{2}$ 吸収を $\alpha_{\mathrm{n}}$ と置き，他の吸 収媒質による吸収係数を $\alpha_{s}$ と置いた。また, 非 励起時の $\mathrm{F}_{2}$ の吸収係数を $100 \mathrm{MW} \mathrm{cm}^{-2}$ まで測定 し, この入力光強度範囲で $F_{2}$ 吸収は非飽和であ る事を確認した。このgnet 渡って積分し, 測定値に対し最小二乗解析を行 って得たレーザーパラメーターをFig. 9に示す。 飽和光強度 $I_{\mathrm{s}}$ は, 希ガスや $\mathrm{F}_{2}$ との衝突による脱 励起速度の増加を反映して, 圧力と共に增加し ている。利得係数，は，低圧では圧力に比例し て増加するが, 1 atm以上では脱励起速度の増 加により飽和する傾向を示した。

$\alpha_{\mathrm{s}}$ と $I_{\mathrm{sa}}$ の圧力依存性をFig.10に示す。 $\alpha_{\mathrm{s}}$ は 利得と同様に圧力と共に増加し, 飽和する振舞 を示した。また， $I_{\mathrm{sa}}$ は， $0.5 \mathrm{~atm}$ においても 60 $\mathrm{MW} \mathrm{cm}^{-2}$ であり, 圧力に非常に強く依存して増

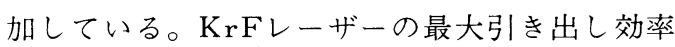
を与える入力光強度 $I$ opt は, 次式により与えら 


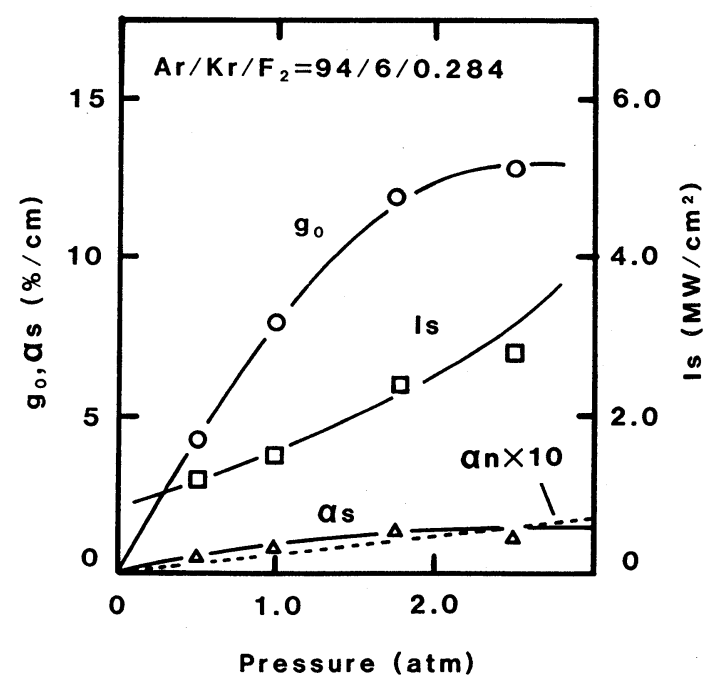

Fig. 9 Laser parameters as a function of gas pressure.

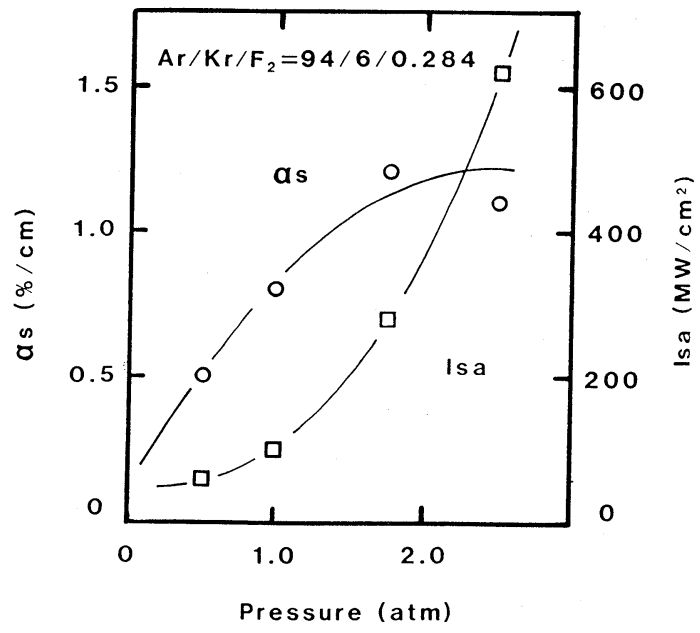

Fig. 10 Absorption coefficient and its saturation intensity. The absorption coefficient by $\mathrm{F}_{2}$ is subtracted.

れる。

$$
I_{\mathrm{opt}} \sim I_{\mathrm{s}}(\sqrt{\gamma}-1) \quad \gamma=g_{\mathrm{o}} / \alpha
$$

$\gamma=10$ を仮定すれば $I_{\mathrm{opt}}$ は $I_{\mathrm{s}}$ の 2 から 3 倍程度で あるので, 吸収飽和光強度は実際のレーザー動 作条件における光強度よりも非常に高い事が分 かる。従って, このような吸収飽和は, KrFレ ーザーの引き出し効率に影響を及ぼす事はない。 また，これまでの発振実験や最大効率点付近ま での増幅実験では，吸収飽和を観測することは
困難である。

\section{3 脱励起過程}

KrFレーザー媒質に高速の電子ビームが入射 すると, レーザーガスを電離し, 大量の 2 次 電子が発生する。この 2 次電子は, レーザー上 準位を脱励起する。レーザーガス圧力が一定の 場合には, 電子密度は励起強度に比例して増加 するので, 高励起強度（ $\left.1 \mathrm{MWcm}^{-3}\right)$ では, 電 子脱励起はレーザー動作に重要な影響を与える。 一方, 希ガスによる 3 体脱励起速度は, 圧力の 2 乗に比例して増加し, 3 体脱励起速度が, 大 気圧以上の圧力におけるレーザー動作に及ぼす 影響は非常に大きい。ここでは，励起強度依存 性，圧力依存性によって得られた飽和光強度の 振舞から, 電子脱励起速度定数, 希ガス 3 体脱 励起速度定数について考察する。

レーザー光強度 $I$ にけるレーザー上準位の 速度方程式は，次式のように書ける。

$$
\frac{\mathrm{d}\left[\mathrm{KrF}^{*}\right]}{\mathrm{d} t}=R_{\mathrm{p}}-\left(\frac{1}{\tau_{\text {eff }}}+\frac{\sigma I}{h \nu}\right) \cdot\left[\mathrm{KrF}^{*}\right]
$$

ここで, $\left[\mathrm{KrF}^{*}\right]$ は $\mathrm{KrF}^{*}$ の数密度, $R_{\mathrm{p}}$ は, 上 準位の励起速度， $\sigma, h \nu$ は, $\mathrm{KrF}^{*}$ の誘導放出 断面積及び光子エネルギー $(5 \mathrm{eV})$ である。ま た, $\tau_{\text {ef } \mathrm{f}}$ は, $\mathrm{KrF}^{*}$ の実効寿命である。 $\mathrm{KrF}^{*}$ の 放射寿命は理論的に6.5 $\mathrm{ns}^{18)}$ と推定されており, 更にレーザー動作条件では，衝突により $2 \mathrm{~ns}$ 程 度に短いと考えられる。従つて, 通常の場合定 常状態を仮定する事ができ，式(6)を零と置くこ とができる。定常状態において, 入力レーザー 光強度 $I$ が, 飽和光強度 $I_{\mathrm{s}}$ に等しいとき, 光子 による脱励起速度は，他の脱励起速度 $1 / \tau_{\text {ef } \mathrm{f}}$ に 等しい。即ち,

$$
\begin{aligned}
& \frac{1}{\tau_{\text {ef f }}}=\frac{\sigma I_{\mathrm{s}}}{h \nu} \\
& =k_{1}\left[e_{\mathrm{s}}\right]+k_{2}\left[\mathrm{~F}_{2}\right] \\
& \quad+\sum k_{3}\left[R_{\mathrm{g}}\right]+\sum k_{4}\left[R_{\mathrm{g}}\right]^{2}+\frac{1}{\tau_{\gamma}}
\end{aligned}
$$

ここで, $e_{\mathrm{s}}, R_{\mathrm{g}}, \tau \gamma$ は, 2 次電子, 希ガス原子 自然放出寿命, 表し， [ ] はその数密度を示す。 また, $k_{1}, k_{2}, k_{3}, k_{4}$ は, 電子, $\mathrm{F}_{2}$, 希ガス 2 
体, 希ガス 3 体衝突による脱励起反応速度定数 である。式(7)より, 飽和光強度 $I_{\mathrm{s}}$ の振舞は, 誘 導放出断面積を比例定数として，レーザー上準 位の脱励起速度を直接反映している事が分かる。

ここで, 電子脱励起速度定数を決定するため に, 電子密度 $\left[e_{\mathrm{s}}\right]$ を以下のようにして求めた。 $\mathrm{KrF}$ rーザーガス中では, 2 次電子は, 高速の 電子ビームによる希ガスの電離により発生する。 この電子ビームによる 2 次電子生成速度 $S$ は, 励起強度を $R_{\mathrm{d}}$, 希ガスの平均エネルギーを $W$, 電子の電荷量を $e_{\mathrm{o}}$ として,

$$
S=\frac{R_{\mathrm{d}}}{e_{\mathrm{o}} W}
$$

と表す事ができる ${ }^{31}$ 。一方，正イオンと電子の 再結合速度に比べ， $F_{2}$ の電子付着速度が非常に 大きいために，レーザーガス中における2 次電 子の消失は， $\mathrm{F}_{2}$ 濃度によって決定される。従っ て, $e_{\mathrm{s}}$ の速度方程式は $k_{5}$ を $\mathrm{F}_{2}$ の解離性電子付 着反応定数として

$$
\frac{\mathrm{d}\left[e_{s}\right]}{\mathrm{d} t}=S-k_{5}\left[\mathrm{~F}_{2}\right]\left[e_{\mathrm{s}}\right]
$$

と書ける。 $\mathrm{F}_{2}$ 濃度0.284\%1.76 atmのレーザー ガス中では， 2 次電子の実効寿命は $1 \mathrm{~ns}$ と非常 に短いので式 $(9)$ に定常状態を仮定して電子密度 を求めると,

$$
\left[e_{\mathrm{s}}\right]=\frac{S}{k_{5} \cdot\left[\mathrm{F}_{2}\right]}
$$

と決定できる。式(10)より，ガス圧力（ $\mathrm{F}_{2}$ 密度） を一定に保った壮態では, 電子密度は, 励起強 度に比例する事が分かる。一方, $\mathrm{F}_{2}$ 濃度を一定 に保ち,レーザーガス圧力を変化させた場合に は，電子生成速度が比例するために電子密度は 一定に保たれる。

Table I は, 各脱励起過程の原理的に期待さ れる励起強度依存性, 圧力依存性である。励起 強度により変化する電子脱励起は, 圧力変化で は一定に保たれ，圧力により変化する $\mathrm{F}_{2}$ や希ガ スとの衝突による脱励起は，励起強度に対し一 定である事が分かる。従って, 励起強度, 圧力 の 2 つの変化から，2次元的な解析を行うこと により個々の脱励起過程を分離した解析が可能
Table I. Pump rate and pressure dependence of the quenching process. The reduction of the $\mathrm{F}_{2}$ number density is calculated to correct "burnup".

\begin{tabular}{c|cc}
\hline & Pump Rate R & Pressure P \\
\hline Radiative & const. & const. \\
Electron & $\propto R$ & const. \\
F $_{2}$ & const. & $\propto P$ \\
Rg 2body & const. & $\propto P$ \\
Rg 3body & $\mathrm{Tg}^{-3}$ & $\propto P^{2}$ \\
\hline
\end{tabular}

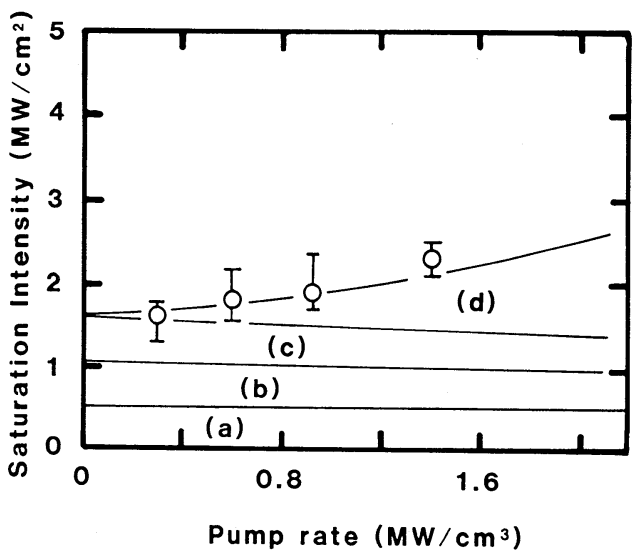

Fig. 11 The quenching rate as a function of pump rate. (a), Radiative;

(b), rare gas 2-body and $F_{2}$; (c), rare gas 3-body, and (d), electron quenching rate.

になる。Fig. 11，12は, 飽和光強度の励起強度, 圧力依存性から求めた, 脱励起過程の詳細であ る。上述のように, 励起強度の変化に対しては, 電子脱励起速度の変化が大きく影響し, 他の脱 励起の変化は小さい。一方, 圧力変化に対して は, 衝突反応, 特に希ガスの 3 体脱励起反応速 度の変化が大きく，電子脱励起の影響は現れな ない。従って，Fig.11の $I_{\mathrm{s}}$ の傾き，Fig.12の ガス圧力零の外插值より電子脱励起速度が求ま 
Table II. Rate constant and the cross section of $\mathrm{KrF}^{*}$-stimulated emission.

\begin{tabular}{|c|c|c|c|c|c|}
\hline Reaction & & & Rate constant & & Reference \\
\hline $\mathrm{F}_{2}+\mathrm{e}_{s}(\mathrm{slow})$ & $\rightarrow$ & $F^{-}+F$ & $7.5 \times 10^{-9}$ & $\mathrm{c} \mathrm{m}^{3} \mathrm{~s}^{-1}$ & 19 \\
\hline$K r F^{*}+h \nu$ & $\rightarrow$ & $\mathrm{Kr}+\mathrm{F}+2 \mathrm{~h} \nu$ & $2.4 \times 10^{-16}$ & $\therefore \mathrm{m}^{2}$ & 18 \\
\hline $\mathrm{Kr} \mathrm{F}^{*}+\mathrm{F}_{2}$ & $\rightarrow$ & $K r+3 F$ & 6. $0 \times 10^{-10}$ & $\therefore \mathrm{m}^{3} \mathrm{~s}^{-1}$ & 20,21 \\
\hline$K r F^{*}+A r$ & $\rightarrow$ & $A r+K r+F$ & 1. $8 \times 10^{-12}$ & $\therefore \mathrm{m}^{3} \mathrm{~s}^{-1}$ & 22 \\
\hline$K r F^{*}+K r$ & $\rightarrow$ & $2 \mathrm{Kr}+\mathrm{F}$ & 2. $0 \times 10^{-12}$ & $c \mathrm{~m}^{3} \mathrm{~s}^{-1}$ & 21 \\
\hline $\mathrm{Kr} \mathrm{F}^{*}+2 \mathrm{Ar}$ & $\rightarrow$ & $\mathrm{ArKr} \mathrm{F}^{*}+\mathrm{Ar}$ & $8 \cdot 0 \times 10^{-32}$ & $\mathrm{c} \mathrm{m}^{6} \mathrm{~s}^{-1}$ & 23 \\
\hline $\mathrm{K} r \mathrm{~F}^{*}+\mathrm{Ar}+\mathrm{Kr}$ & $\rightarrow$ & $\mathrm{Ar} \mathrm{Kr} \mathrm{F}^{*}+\mathrm{Kr}$ & 8. $0 \times 10^{-32}$ & $\mathrm{c} \mathrm{m}^{6} \mathrm{~s}^{-1}$ & 24 \\
\hline $\mathrm{Kr} \mathrm{F}^{*}+\mathrm{Ar}+\mathrm{Kr}$ & $\rightarrow$ & 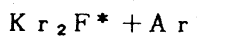 & 4. $0 \times 10^{-31}$ & $c m^{6} s^{-1}$ & 24 \\
\hline $\mathrm{Kr} \mathrm{F}^{*}+2 \mathrm{Kr}$ & $\rightarrow$ & $\mathrm{Kr}_{2} \mathrm{~F}^{*}+\mathrm{Kr}$ & $6.8 \times 10^{-31}$ & $\mathrm{c} \mathrm{m}^{6} \mathrm{~s}^{-1}$ & 25,26 \\
\hline $\mathrm{KrF} \mathrm{F}^{*}+\mathrm{e}_{s}$ & $\rightarrow$ & $\mathrm{Kr}+\mathrm{F}+\mathrm{e}_{s}$ & 4. $5 \times 10^{-7}$ & $\mathrm{c} \mathrm{m}^{3} \mathrm{~s}^{-1}$ & this work \\
\hline
\end{tabular}

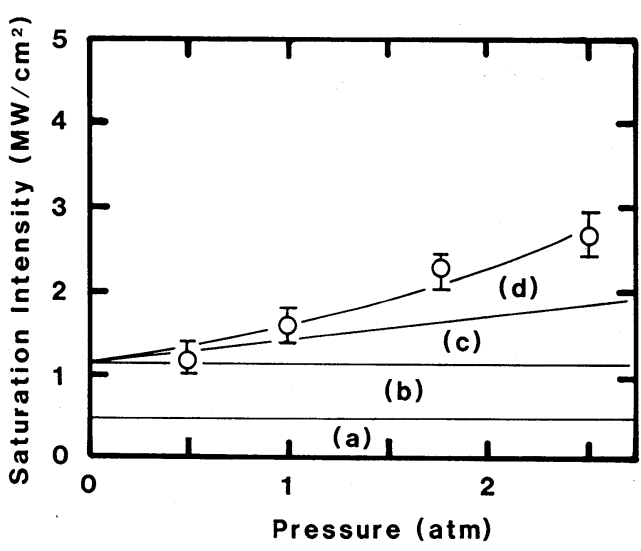

Fig. 12 The quenching rate as a function of gas pressure. (a), Radiative; (b), electron; (c), rare gas 2body and $\mathrm{F}_{2}$, (d), rare gas 3body quenching rate.

ク, Fig. 11の励起強度零の外插値, Fig. 12 の 傾きよりガスとの衝突による脱励起速度を求め る事ができる。このとき， 3 体脱励起速度はガ ス温度に対しー3 乗の依存性 ${ }^{24}$ を持つことを 考虑した。また， 2 次電子付着やHarpoon反応 による $\mathrm{F}_{2}$ の減少量を計算により求め, 測定時刻 における $\mathrm{F}_{2}$ の数密度を決定した。Table IIに計 算に使用した， $F_{2}$ ，希ガス 2 体，希ガス 3 体脱 励起速度定数, $\mathrm{F}_{2}$ の解離性付着断面積, $\mathrm{KrF}^{*}$ の誘導放出断面積を示す。これまでに測定され た 3 体衝突脱励起速度定数の值 ${ }^{25}$ 27) は, 1 桁 近い広がりを持っているので, 解析は, $\mathrm{F}_{2}$, 希 ガス 2 体の脱励起速度定数を固定しを希ガス 3

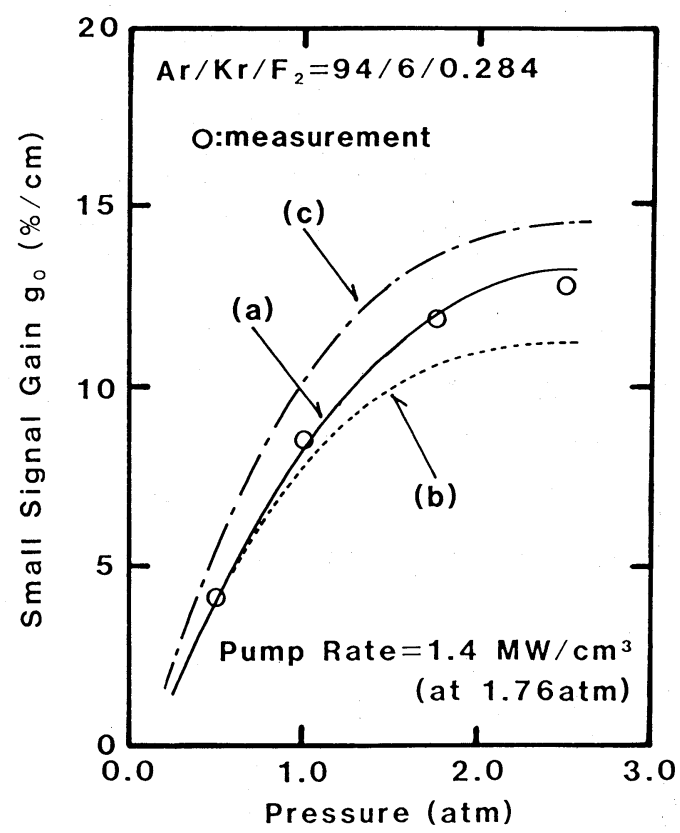

Fig. 13 Calculated small signal gain coefficient as a function of gas pressure. (a), The electron quenching rate constant $k_{\text {ele }}=$ $4.5 \times 10^{-7} \mathrm{~cm}^{3} \mathrm{~s}^{-1}$ and 3 -body rate constants in Table 2 with gas temperature to the $-3 \mathrm{rd}$ power $\left(\mathrm{Tg}^{-3}\right)$ dependence in 3-body rare gas collisional quenching; (b), $k_{\mathrm{e} 1 \mathrm{e}}=2.0 \times 10^{-7} \mathrm{~cm}^{3} \mathrm{~s}^{-1}$. (c), $k_{\mathrm{ele}}=4$ $4.5 \times 10^{-7} \mathrm{~cm}^{3} \mathrm{~s}^{-1}$ and gas temperature to the -0.5 power $\left(\mathrm{Tg}^{-0.5}\right)$ dependence in 3 -body rare gas quenching. Open circles indicate the measurements. 
体, 電子脱励起速度定数をパラメーターとして 行った。解析の結果, Table IIに示した 3 体脱 励起速度定数を用いた場合に, 飽和光強度の励 起強度依存性, 圧力依存性が矛盾なく説明され 電子脱励起速度定数 $4.5 \times 10^{-7} \mathrm{~cm}^{3} \mathrm{~s}^{-1}$ が求まつ た。この值は,これまで用いられていた測定値 ${ }^{281}$ の2.3倍に相当する。電子密度決定に用いた $\mathrm{F}_{2}$ の電子付着定数には電子温度依存性があるが, 今回の測定はレーザー動作条件における $\mathrm{KrF}^{*}$ の実効的な電子脱励起量を正確に決定したこと に他ならない。 $\mathrm{KrF}^{*}$ 全脱励起量に対する電子 脱励起量の割合は, 低圧力において非常に大き な割合を占め, 圧力 $0.5 \mathrm{~atm}$ では $50 \%$ に相当す る。

Table IIに示した反応速度定数を用いて, 小 信号利得の圧力依存性を計算した結果を Fig. 13 に示す。測定値と計算値は非常によく一致し, 反応速度定数が正確に決定できている事が分か る。同様に, 励起強度に対する小信号利得の振

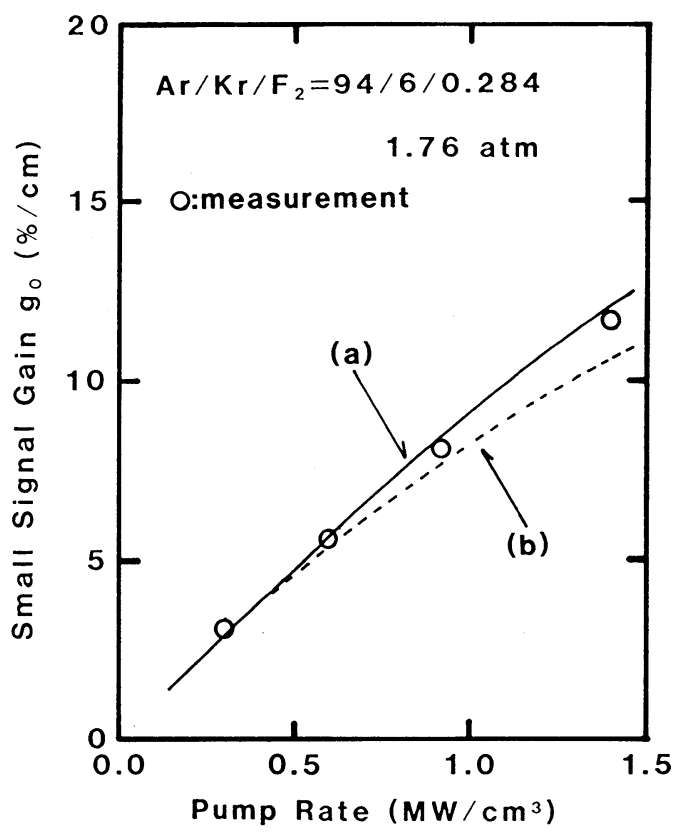

Fig.14 Calculated small signal gain as a function of the pump rate. Gastemperature dependence of the quenching rate constant in 3 -body rare gas quenching. (a), $\mathrm{Tg}^{-3}$; (b), $\mathrm{Tg}^{-0.5}$.
舞（Fig. 14）も測定値に極めてよく一致した。 比較のために, これまで用いられて来た電子脱 励起速度定数用いると, Fig. 13の一点鎖線が示 す様に低圧力における小信号利得の傾きが大き く異なる。また, 報告されている 3 体衝突脱励 起速度の温度依存性には大きな開きがある。 3 体脱励起速度の温度依存性をガス温度に対し一 0.5 乗 $^{14}$ に取った場合には，Fig. 13，14の点 線が示すように高圧力, 高励起強度側で小信号 利得の低下が見られた。これらの結果から，3 体脱励起速度にー 3 乗の温度依存性を用いたの は妥当であった。

\section{5.まとめ}

高光強度における増幅実験を行い, 励起強度, レーザーガス圧力に対するレーザーパラメー夕 一の振舞を観測した。1 ${ }^{6}$ に及び入力光強度を 変化させることによって, レーザーパラメータ 一を分離して正確に決定することができた。測 定したレーザーパラメーターを用いて， $\mathrm{KrF}^{*}$ の脱励起速度の温度依存性や圧力依存性につい て考察し, 実効的な電子脱励起速度を決定した。 求められた電子脱励起速度定数は， $4.5 \times 10^{-7}$ $\mathrm{cm}^{3} \mathrm{~s}^{-1}$ であり, 従来值の 2.3 倍であった。電子脱 励起過程は, 高励起条件 (>1 $\left.\mathrm{MW} \mathrm{cm}^{-3}\right)$ では 全脱励起反応の約 $30 \%$ 占め, $\mathrm{KrF}^{*}$ の主要な 脱励起反応であることが分かった。求めた脱励 起反応速度定数は, 励起強度やガス圧力に対す る小信号利得の振舞を正確に説明した。

\section{参 考文 献}

1) A.M. Hunter et al.: IEEE QE-22 (1986) 386.

2) 植田：レーザー研究 6 (1987) 342 .

3) D.D. Lowenthal and J.M. Eggleston: IEEE QE-22 (1986) 1165.

4) A. Sasaki, K. Ueda, H. Takuma, T. Kasuya: Proc. International symposium on short wa-velength lasers and their applications Nov. 11-13 (1987) ILE Osaka (to be pub lished).

5) 植田, 金田, 北川, 宅間：レーザー研究 11 (1983) 576 .

6) 植田, 金田, 佐々木, 宅間：レーザー研究 12 
(1984) 357.

7) K. Hakuta et al.: J. Appl. Phys. 61 (1987) 2113.

8) F. Kannari, M. Obara and T. Fujioka: J. Appl. Phys. 57 (1985) 4309.

9) A. Suda, M. Obara and A. Noguchi: Fusion Technology 11 (1987) 548.

10) K. Ueda, H. Nishioka and H. Takuma: Proc. SPIE 710 (1986) 7.

11) P.J.M. Peters et al.: Appl. Phys. B43 (1987) 253

12) V.H. Shui: Appl. Phys. Lett. 34 (1979) 203.

13) A. Mandl. D. Klimek and J.H. Parks: J. Appl. Phys. 55 (1984) 3940.

14) W.D. .Kimura and E.T. Salesky: Appl. Phys. Lett. 48 (1986) 897.

15) J.K. Rice et al.: IEEE QE-16 (1980) 1315.

16) E.T. Salesky and W.D. Kimura: Appl. Phys. Lett. 46 (1985) 927.

17) K. Ueda, H. Nishioka and H. Takuma:

- Proc. BEAMS' 86 June 9-12 (1986) 663.

18) T.H. Dunning et al.: Appl. Phys. Lett. 28 (1976) 649.

19) C.B. Edwards and F.O. Neil: Laser and Particle Beams 1 part 1 (1983) 8. 1.
20) J.E. Velazco et al.: J. Chem. Phys. 65 (1976) 3468.

21) M. Rokni et al.: Phys. Rev. A16 (1977) 2216.

22) J.G. Eder et al.: Appl. PHys. Lett. 32 (1978) 733.

23) J.A. Mangano et al.: Appl. Phys. Lett. 31 (1977) 26.

24) V.H. Shui et al.: Appl. Phys. Lett. 36 (1980) 135.

25) G.P. Quigley et al.: Appl. Phys. Lett. 32 (1978) 627.

26) J.G. Eder et al.: Appl. Phys. Lett. 32 (1978) 733.

27) W.L. Morgan et al.: Phys. Rev. A23 (1981) 1256.

28) D.W. Trainor and J.H. Jacob: Appl. Phys. Lett. 37 (1980) 675.

29) W.W. Rigrod: J. Appl. Lett. 36 (1965) 2487.

30) R. Shimizu et al.: Japan. J. Appl. Phy's 9 (1970) 1291.

31) R.A. Lowrv and G.H. Miller: Phys. Rev. 109 (1958) 826. 